\title{
PEMANFAATAN SIARAN TELEVISI EDUKASI (TVE) UNTUK MENDUKUNG PROGRAM SERTIFIKASI GURU
}

Oleh: Jaka Warsihna*)

\section{Abstrak}

Menurut UU nomor 15 tahun 2005 tentang Guru dan Dosen serta UU Nomor 20 tahun 2004 tentang Sistem Pendidikan Nasional menegaskan bahwa dalam peningkatan mutu pendidikan nasional harus dimulai dari peningkatan mutu guru. Salah satu ciri guru yang bermutu yaitu lulus program sertifikasi. Agar semua guru di Indonesia selalu dapat meningkatkan mutunya maka perlu ada pemberian informasi dan pelatihan yang serentak dan komprehensif. Mengingat jumlah guru yang begitu banyak dan sangat sulit untuk mengikuti pelatihan secara serentak, maka perlu ada pelatihan jarak jauh yang memanfaatkan media elektronik. Salah satu media elektronik yang sangat memungkinkan dan efisien yatiu siaran televisi. Saat ini Depdiknas telah memiliki siaran televisi pendidikan yang disebut Televisi Edukasi (TVE). Siaran TVE dapat diakses oleh guru di seluruh wilayah Indonesia, sehingga guru-guru dapat mengikuti pelatihan dalam rangka meningkatkan kompetensinya dan mendapatkan informasi sertifikasi guru secara cepat tanpa harus meninggalkan kelas.

Kata Kunci: Televisi Edukasi (TVE) dan sertifikasi

\section{A. PENDAHULUAN}

Prioritas utama upaya peningkatan mutu pendidikan nasional harus dimulai dari peningkatan mutu guru. Selama ini guru berada pada posisi yang dilematis, di satu sisi dituntut bekerja secara profesional di sisi lain kesejahteraannya masih relatif rendah. Sebagai tenaga profesional guru dituntut menguasai isi bidang studi, memahami karakteristik peserta didik, melakonkan pembelajaran yang mendidik, kemauan dan kemampuan mengembangkan profesionalisme dan kepribadian. Undang-undang RI No. 14 Tahun 2005 tentang Guru dan Dosen (UUGD) mengamanatkan adanya perubahan situasi tersebut, dengan cara menempatkan guru sebagai profesi. Sebagai konsekuensi dari amanat UUGD tersebut maka dalam upaya meningkatkan kesejahteraan guru, akan diberikan tunjangan profesi bagi para guru yang memenuhi persyaratan (lulus serifikasi). Sertifikasi guru disini menjadi titik tolak upaya peningkatan kualitas guru yang disertai dengan peningkatan kesejahteraan.

Sertifikasi menurut Pasal 1 butir (11) UUGD, adalah proses pemberian sertifikat pendidik kepada guru dan dosen. Sertifikat pendidik diberikan kepada guru dan dosen yang dinyatakan lulus uji sertifikasi terhadap empat kompetensi sesuai tuntutan UUGD, yaitu kompetensi kepribadian, kompetensi pedagogi, kompetensi profesional dan

*) Drs. Jaka Warsihna, M.Pd., Peneliti Bidang Teknologi Pendidikan, Pusat Teknologi Informasi dan Komunikasi Pendidikan (Pustekkom)-Departemen Pendidikan Nasional 
kompetensi sosial. Persyaratan yang harus dipenuhi guru untuk dapat mengikuti uji sertifikasi adalah guru yang memiliki kualifikasi minimal S1/D4. Pelaksanaan uji sertifikasi pendidik merupakan representasi dari evaluasi secara cermat dan komprehensif yang terkait dengan aspek aspek pembentuk sosok guru yang kompeten dan profesional.

Tuntutan evaluasi secara cermat dan komprehensif dalam uji sertifikasi guru di atas mengacu pada amanat isi pasal 11 ayat (3) UUGD yang menyebutkan bahwa sertifikasi pendidik dilaksanakan secara objektif, transparan, dan akuntabel. Secara cermat peserta uji sertifikasi dituntut untuk memenuhi berbagai persyaratan dan mengikuti beberapa tahapan yang ditetapkan dalam uji sertifikasi guru. Sedangkan secara komprehensif, uji sertifikasi guru dilakukan untuk mengukur keseluruhan penguasaan kompetensi yang diamanatkan oleh UUGD secara terintegrasi dan holistik, yang tampak dalam kinerja guru secara riil di dalam kelas. Dengan diperolehnya sertifikat pendidik sebagai salah satu indikator guru yang profesional, maka sesuai Pasal 16 UUGD guru berhak mendapatkan insentif yang berupa tunjangan profesi. Besar insentif tunjangan profesi guru yang diamanatkan oleh UUGD adalah sebesar satu kali gaji pokok untuk setiap bulannya. Hal ini dapat dikatakan bahwa secara kuantitatif, besarnya tunjangan profesi guru yang telah memiliki sertifikat pendidik selaras dengan tingkat kepangkatan dan golongan guru yang bersangkutan.

Tunjangan profesi guru, sesuai amanat UUGD, diberikan kepada para guru, baik yang berstatus sebagai pegawai negeri sipil (PNS) yang biasa disebut guru negeri maupun guru yang berstatus non PNS, yang biasa disebut sebagai guru swasta, selama yang bersangkutan memiliki sertifikat pendidik. Dengan kata lain, tunjangan profesi diberikan kepada semua guru tetap yang bertugas pada satuan pendidikan dan diangkat oleh pemerintah, pemerintah daerah, atau satuan pendidikan yang diselenggarakan masyarakat yang memiliki izin operasional dari pemerintah atau pemerintah daerah.
Dengan adanya UUGD yang mewajibkan guru di semua jenjang dan jenis pendidikan untuk mengikuti dan lulus uji sertifikasi, diharapkan guru dalam melaksanakan profesinya sebagai agen pembelajaran akan selalu meningkatkan kompetensi yang dituntut oleh UUGD (standar kompetensi) secara berkelanjutan dan mandiri. Dengan kondisi obyektif di lapangan, yaitu adanya beragam kondisi geografis, sosial budaya, latar belakang pendidikan, kualifikasi pendidikan, dan kompetensi guru, serta persepsi masyarakat di negara kita, maka kemungkinan implementasi sertifikasi guru perlu waktu dan secara bertahap. Hal ini bisa kita maklumi berdasarkan pada jumlah guru yang cukup besar, jumlah guru yang belum berkualifikasi S1/D4 juga cukup besar, dan adanya variasi penguasaan kompetensi guru yang cukup besar di berbagai jenis dan jenjang pendidikan. Di samping itu, pemahaman dan persepsi masyarakat terhadap sertifikasi guru sebagai upaya peningkatan kualitas yang disertai dengan kesejahteraan bagi para guru masih beragam.

Untuk mengakomodasi keberagaman kondisi di atas dan memfasilitasi keberhasilan sertifikasi guru, maka diperlukan suatu upaya strategis dalam penyelenggaraan dan pengembangan teknologi informasi dan komunikasi untuk mendukung keberhasilan program peningkatan kualifikasi guru yang belum mencapai S1/D4, memfasilitasi peningkatan kompetensi guru, dan persiapan mengikuti uji sertifikasi bagi guru sampai mendapatkan guru memperroleh sertifikat pendidik. Salah satu bentuk pemanfaatan teknologi informasi dan komunikasi yang dipandang sesuai dengan variasi karakteristik geografis, karakteristik sosial budaya, karakteristik sebaran variasi kualifkasi dan kompetensi, karakteristik variasi persepsi masyarakat, maka penyelenggaraan dan pengembangan teknologi informasi dan komunikasi (ICT), seperti pemanfaatan televisi edukasi (TVE), menjadi sangat penting.

Penggunaan TVE sebagai medium baru pendidikan dan pembelajaran merupakan 
program fasilitasi yang sangat cocok untuk karakteristik permasalahan pendidikan seperti yang terjadi di Indonesia. Hal ini dapat ditunjukkan dengan indikator-indikator penyelenggaraan dan pengembangan TVE untuk mendukung keberhasila program di atas dapat diperikan: (1) tingkat ke-masal-an penyajian informasi pembelajaran, televisi yang mampu menembus batas-batas geografis. (2) televisi memiliki daya tarik bagi target sasaran/masyarakat karena memiliki keunikan kombinasi teknologi visual dan audio; (3) keberadaan televisi sudah tidak asing lagi dimasyarakat, dan sudah menjangkau ke wilayah yang sangat luas sesuai karakteristik wilayah negara Republik Indonesia yang terpencil dan terpencar; (4) dapat dikendalikan dari sentral relay untuk penjaminan mutu kualitas isi, kualitas siaran, dan kualitas tampilan; dan (5) kemudahan untuk diulang penayanganya, direvisi isi program dan tampilannya yang disesuaikan dengan tingkat perkembangan yang terjadi di masyarakat.

Berdasarkan pertimbangan-pertimbangan di atas, maka Pusat Informasi Teknologi dan Komunikasi Pendidikan (Pustekkom Depdiknas) sesuai dengan tugas dan fungsinya, akan meningkatkan program Televisi Edukasi (TVE) yang sudah dimiliki. Upaya peningkatan ini dimaksudkan untuk mendukung keberhasilan program salah satunya sertifikasi guru.

\section{B. PERMASALAHAN}

Pelatihan jarak jauh memanfaatkan siaran TVE dalam rangka peningkatkan kompetensi dan sertifikasi guru perlu suatu metode dan strategi yang khusus. Untuk itu diperlukan suatu model siaran serta pemanfaatannya agar dapat berjalan dengan baik. Bagaimanakah model siaran dan strategi pemanfaatan siaran TVE sebagai pendukung program sertifikasi guru yang efektif dan efisien?

\section{PEMBAHASAN}

\section{Televisi Edukasi (TVE)}

Perluasan dan pemerataan pendidikan yang bermutu hingga ke pelosok negeri dan relevan dengan kebutuhan masyarakat harus ditempatkan pada prioritas utama dalam pembangunan pendidikan. Salah satu kendala dalam pemerataan pendidikan di Indonesia adalah cakupan geografisnya yang luas. Hal ini memerlukan modernisasi pada sistem dan jaringan informasi menggunakan Information Communication Technology (ICT) yang memadai. Luasnya wilayah kedaulatan Republik Indonesia dan bervariasinya sebaran penduduknya dapat dipersatukan dengan jejaring teknologi informasi. Dalam konteks ini, TVE dapat menjadi wahana strategis untuk membangun kesadaran kolektif (collective conscience) sebagai warga bangsa dan mengukuhkan ikatan-ikatan sosial, dengan tetap menghargai keragaman budaya, ras, suku-bangsa, dan agama, sehingga dapat memantapkan keutuhan nasional.

Penggunaan TVE sebagai medium baru pendidikan dan pembelajaran merupakan program fasilitasi yang sangat cocok untuk karakteristik permasalahan pendidikan seperti tersebut di atas dan berpotensi dapat mengatasinya. Potensi televisi sebagai media pendidikan dan pembelajaran didukung oleh keunikan yang dibawa teknologi ini. Belum ada media teknologi komunikasi yang mampu menandingi tingkat ke-masal-an televisi pada saat ini, yang mampu menembus batas-batas geografis. Radio yang dulu termasuk media paling masal sekarang mulai tergeser oleh televisi. Televisi memiliki daya tarik luar biasa karena memiliki keunikan kombinasi teknologi visual dan audio.

Dalam praktik pendidikan dan pembelajaran dikenal tiga khasanah teori atau pendekatan belajar yang menjadi pijakan setiap keputusan pembelajaran, yakni teori behavioristik, kognitivistik, dan konstruktivistik. Ketiga khasanah teori belajar ini dapat menjadi satu kesatuan landasan pengembangan TVE. Dalam TVE, perbedaan perspektif teoretik dapat menambah nilai desain dan sistem pembelajaran. Posisi-posisi kunci konsep behavioris, kognitivis, dan konstruktivis dapat dikombinasikan tanpa tumpang tindih ke dalam desain pembelajaran 
TVE. Misalnya, mekanisme ujian (ulangan) dan pemberian umpan balik dikaitkan dengan pembelajaran yang berisi faktual, atau tentang "apa", yang di dalam pandangan behavioris sebagai bentuk perubahan tingkah laku yang teramati sebagai respon terhadap stimuli eksternal (Standridge, 2002). Sederhananya, desain pesan TVE yang dialogis kritis, pesan yang terstruktur, dan interaktif yang didasarkan pada prinsipprinsip perkembangan kognitif memberikan jaminan keefektifan TVE.

Banyak bukti empirik yang menunjukkan keberhasilan program televisi pendidikan di berbagai negara. Sebagai contoh dapat disebut India (Chaudhary, 1992), Mexiko, Brazil (Telecurso 2000), dan China (Chunjie \& Yuxia, 1994). yang berhasil menggunakan televisi pendidikan. Belajar dari pengalaman keberhasilan banyak negara yang karakteristik geografi dan demografinya tak jauh berbeda dengan Indonesia, maka penggunaan televisi pendidikan berpotensi untuk meningkatkan mutu layanan pendidikan di Indonesia. TVE yang dimaksudkan untuk pemerataan mutu layanan dan percepatan peningkatan mutu pendidikan nasional cukup potensial dikembangkan menjadi bagian integral dari skema pembaruan pendidikan nasional, pembaruan pendekatan pembelajaran, pembaruan standar lulusan dan kurikulum, pembaruan buku teks, pembaruan metode pembelajaran, pembinaan dan pemeliharaan profesionalitas guru, dan pembaruan peran guru.

Penggunaan televisi sebagai media pembelajaran jarak jauh di Indonesia pertama kali dilakukan oleh Universitas Terbuka mulai pertengahan tahun 1980an melalui saluran TVRI, satu-satunya televisi nasional yang ada pada saat itu. Secara konseptual siaran belajar jarak jauh TVRI itu dapat disebut program TV Pendidikan. Ketika pemerintah membuka ijin pendirian stasiun televisi swasta pada tahun 1990, pada tanggal 23 Januari 1991, Presiden Republik Indonesia, Soeharto, meresmikan stasiun Televisi Pendidikan Indonesia (TPI), sebuah stasiun televisi swasta yang mengkhususkan diri di bidang Pendidikan dan Pembelajaran. Dalam operasional penyiarannya TPI bekerja sama dengan Departemen Penerangan (TVRI). Sedangkan dalam memproduksi program-program televisi pendidikan dan pembelajar-an TPI bekerja sama dengan Pusat Teknologi Komunikasi (Pustekkom) Departemen Pendidikan dan Kebudayaan. Kerjasama antara TPI dengan Pustekkom untuk memproduksi dan menyiarkan program televisi pembelajaran berakhir pada tahun 1998. Dengan berlakunya kurikulum 2004, Pustekkom mulai lagi untuk memproduksi program-program pembelajaran yang dapat digunakan sebagai sumber belajar di sekolah.

Melihat kebutuhan program-program pembelajaran di sekolah pada tanggal 12 Oktober 2004, menteri Pendidikan Nasional meresmikan sebuah stasiun televisi pendidikan yang diberi nama Televisi Edukasi (TVE) yang stasiunnya berada di Kantor Pustekkom. TVE mendapat dukungan Prof. Dr. Bambang Sudibyo, Menteri Pendidikan Nasional pengganti Prof. Malik Fajar, ditandai dengan diresmikannya stasiun relay TVE di 80 kabupaten dan kota. Pengelolaan dan operasionalisasi TVE diserahkan kepada Pustekkom di bawah bimbingan Menteri dan Sekretaris Jenderal Departemen Pendidikan Nasional. Berbagai program pembelajaran sebagai sumber belajar yang dikembangkan oleh Pustekkom, disiarkan melalui siaran TVE.

Stasiun TVE yang bermoto Santun dan Mencerdaskan ini disiarkan melalui satelit Telkom I dengan frekuensi siaran 3785 MHz. Simbol Rate (SRI) 4000-LNB/LO 5150-Video Pid 0308-Audio Pid 0256PCR Pid 8190. Materi yang disiarkan TVE boleh dikatakan 100\% bermuatan pendidikan dan pembelajaran. Iklan-iklan pun diseleksi agar tidak ada iklan yang bertentangan prinsip-prinsip pendidikan dan pembelajaran. Karena berbagai hal, kini TVE belum bisa melakukan siaran terbuka (open broadcast). Skema penayangan program-program TVE digambarkan berikut (Gambar 1 dan 2). 


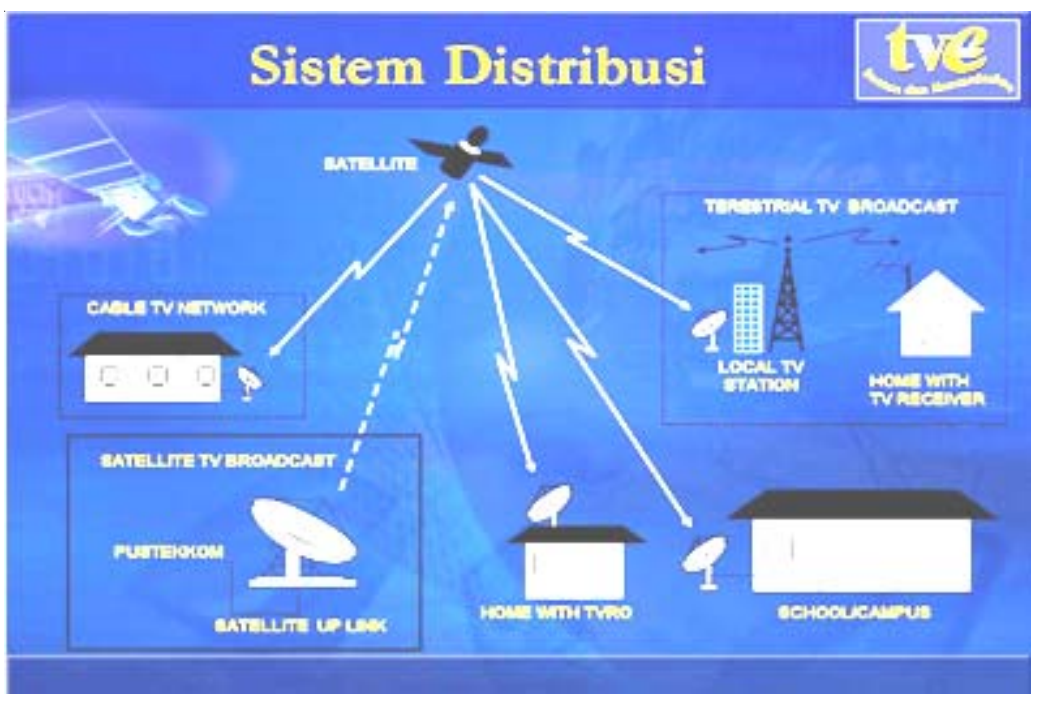

Gambar 1. Sistem Distribusi TVE

(Sumber: Pustekkom, 2004)

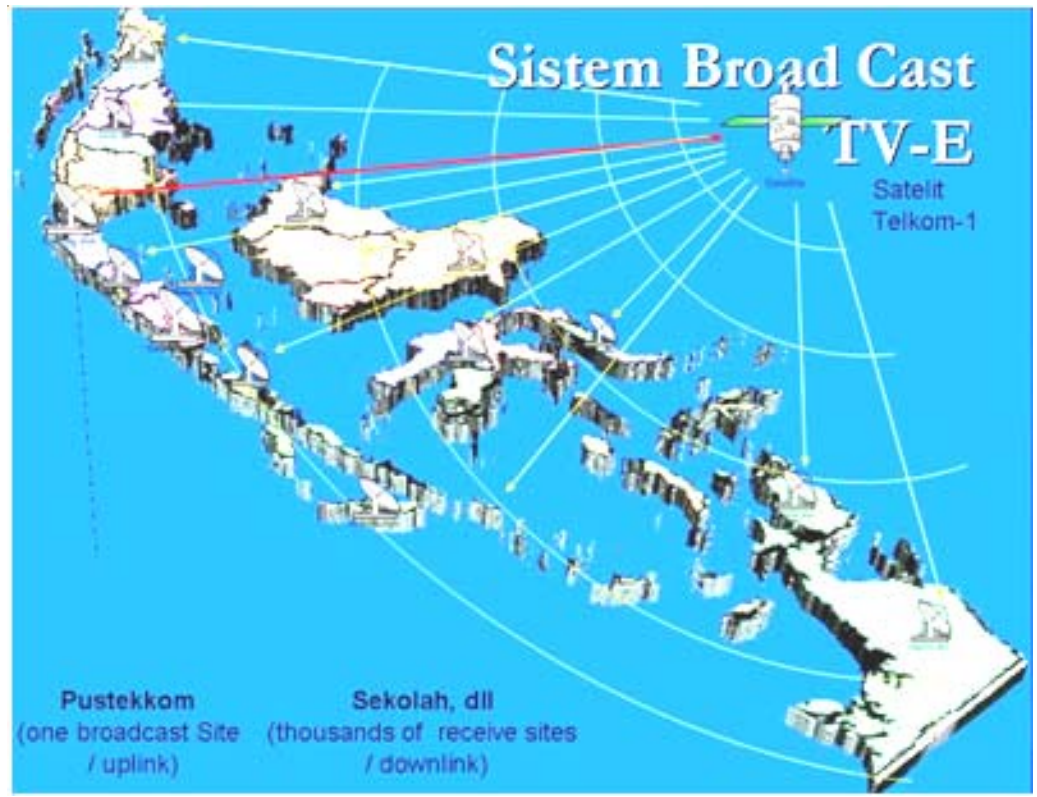

Gambar 2. Sistem Broadcast TVE di Wilayah Indonesia

(Sumber: Pustekkom, 2004)

Untuk mengatasi permasalahan yang berhubungan dengan sistem siarannya yang masih harus menggunakan antena parabola pada penerimaan program pembelajaran yang ditayangkan TVE, maka Departemen Pendidikan Nasional melalui Pustekkom menjalin kerjasama dengan 90 stasiun TV lokal dan SMKSMK yang tersebar di berbagai kota di Indonesia untuk merelay siaran pembelajaran yang ditayangkan TVE. Dengan demikian para siswa dan pemirsa lainnya (termasuk guru dan masyarakat pada umumnya) dapat menyaksikan materi-materi tayangan tersebut secara terestrial, artinya tidak harus menggunakan antene parabola, cukup mengarahkan channel TV ke stasiun TV lokal yang menayangkan materi-materi pembelajaran yang ditayangkan TVE. Penyelenggaraan Siaran TVE bisa dilakukan di rumah masing-masing.

Khusus dalam rangka menunjang program peningkatan kualitas guru, TVE membuka saluran 2. Saluran 2 ini materi yang ditayangkan meliputi peningkatan kompetensi guru, kualifikasi guru, dan menunjang sertifikasi guru, serta informasi pendidikan. 


\section{Sertifikasi Guru}

Pasal 1 butir (11) UUGD menyebutkan bahwa sertifikasi adalah proses pemberian sertifikat pendidik kepada guru dan dosen. Tentu saja dengan logika bahwa yang ber-sangkutan terbukti telah menguasai kedua hal yang diper-syaratkan di atas (kualifikasi pendidikan minimum dan penguasaan kompetensi guru). Untuk kualifikasi pendidikan minimum, buktinya dapat diperoleh melalui ijazah (D4/SI). Namun sertifikat pendidik sebagai bukti penguasaan kompetensi minimal sebagai guru harus dilakukan melalui suatu evaluasi yang cermat dan komprehensif dari aspek aspek pembentuk sosok guru yang kompetensi dan profesional. Tuntutan evaluasi yang cermat dan komprehensif ini berlandaskan pada isi Pasal 11 ayat (3) UUGD yang menyebutkan bahwa sertifikasi pendidik dilaksanakan secara objektif, transparan, dan akuntabel. Jadi, sertifikasi guru dari sisi proses akan berbentuk uji kompetensi yang cermat dan komprehensif. Jika seorang guru/calon guru dinyatakan lulus dalam uji kompetensi ini, maka dia berhak memperoleh sertifikat pendidik.

Sertifikasi guru bertujuan untuk menentukan tingkat kelayakan seseorang guru dalam melaksanakan tugas sebagai agen pembelajaran di sekolah dan sekaligus memberikan sertifikat pendidik bagi guru yang telah memenuhi persyaratan dan lulus uji sertifikasi. Adapun manfaat uji sertifikasi guru dalam kerangka makro upaya peningkatan kualitas layanan dan hasil pendidikan adalah sebagai berikut. Pertama, melindungi profesi guru dari praktik praktik layanan pendidikan yang tidak kompeten sehingga dapat merusak citra profesi guru itu sendiri. Kedua, melindungi masyarakat dari praktik praktik pendidikan yang tidak berkualitas dan profesional yang akan dapat menghambat upaya peningkatan kualitas pendidikan dan penyiapan sumberdaya manusia di negeri ini. Ketiga, menjadi wahana penjaminan mutu bagi LPTK yang bertugas mem-persiapkan calon guru dan juga berfungsi sebagai kontrol mutu bagi pengguna layanan pendidikan. Keempat, menjaga lembaga penyelenggara pendidikan dari keinginan intemal dan tekanan ekstemal yang potensial dapat menyimpang dari ketentuan--ketentuan yang berlaku.

Wacana terbaru yang berkembang dalam Permen Diknas RI No.18/2007, uji sertifikasi guru dalam jabatan tidak lagi meliputi tahapan uji tulis, uji kenerja, self appraisal dan portofolio, serta penilaian atasan, tetapi hanya melalui penilaian portofolio sebagai gawang utama. Penilaian portofolio secara esensi akan menilai kinerja dan prestasi guru selama interval waktu tertentu (beberapa tahun terakhir, misalnya 5 tahun terakhir) dalam perannya sebagai agen pembelajaran. Indikator kinerja dan prestasi yang dimaksudkan dalam penilaian portofolio adalah bukti-bukti fisik dan/atau pengesahannya oleh lembaga atau pejabat yang berwenang.

Guru yang dinyatakan lulus melalui penilaian portofolio, mereka akan diberikan sertifikat pendidik. Bagi guru yang dinyatakan belum lulus melalui penilaian portofolio dikelompokkan menjadi 2 yaitu: (a) kelompok yang harus melengkapi kekurangan portofolio melalui kegiatan mandiri, dan (b) kelompok yang harus mengikuti kegiatan pendidikan dan pelatihan (diklat) profesi.

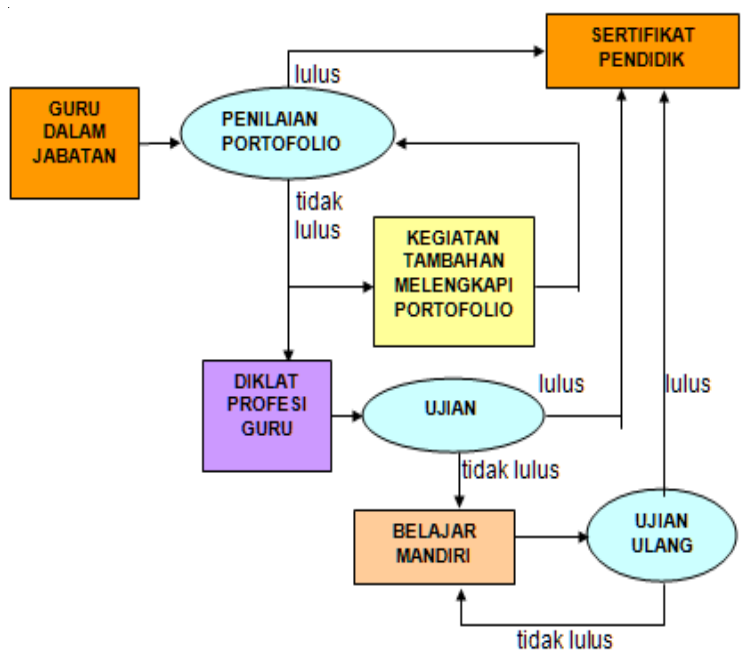

Gambar 3. Diagram Alur Alternatif Sertifikasi Guru Dalam Jabatan

Diambil dari Naskah Akademik Siaran TVE 
Kelompok guru yang mengikuti kegiatan mandiri untuk melengkapi portofolio setelah siap, maka akan dilakukan penlaian lagi oleh lembaga sertifikasi. Apabila dinyatakan lulus, ia berhak mendapat sertifikat pendidik. Jika yang bersangkutan masih belum lulus, maka ia harus melakukan kegiatan mandiri melengkapi kekurangan portofolio. Kelompok guru yang mengikuti diklat profesi pada akhir kegiatan akan dilakukan uji kompetensi. Apabila mereka dinyatakan lulus, maka akan diberikan sertifikat pendidik. Apabila mereka dinyatakan tidak lulus, mereka diberi kesempatan untuk belajar mandiri sampai ia siap untuk mengikuti uji ulang sertifikasi. Adapun alur pelaksanaannya disajikan pada gambar 2 .

Sedangkan target peningkatan kualifikasi dan sertifikasi guru adalah sebagai berikut.

Tabel 3. Target Peningkatan Kualifikasi dan Sertifikasi Guru

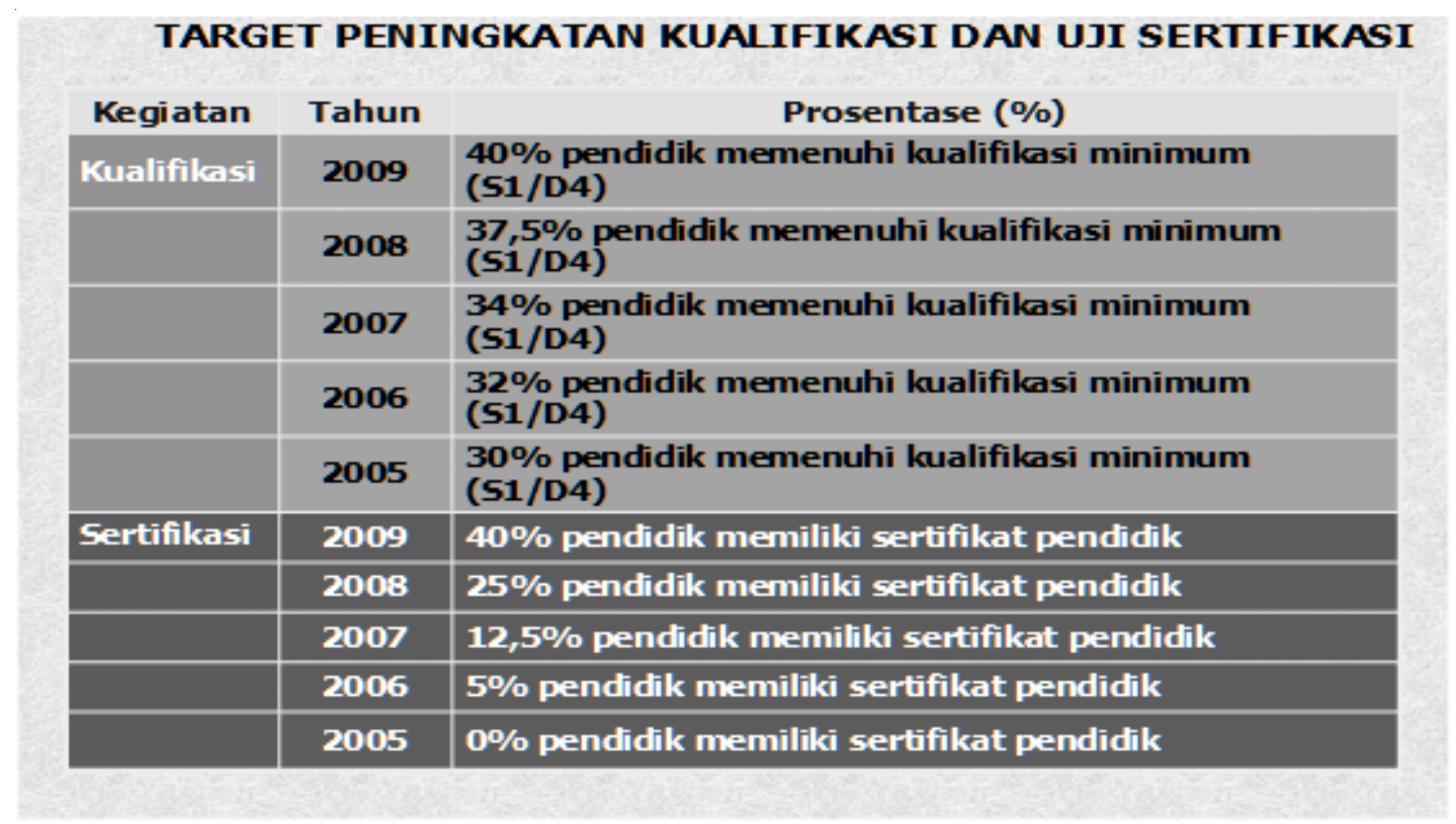

Sumber: Dirjen PMPTK, tahun 2007

4. Model Penyelenggaraan TVE dalam Rangka Mendukung Keberhasilan Persiapan Menyongsong Sertifikasi Guru

Dalam pelaksanaan sertifikasi untuk guru dalam jabatan difokuskan melalui penilaian portofolio. Penilaian portofolio secara esensi akan menilai kinerja dan prestasi guru selama interval waktu tertentu (beberapa tahun terakhir, misalnya 5 tahun terakhir) dalam perannya sebagai agen pembelajaran. Indikator kinerja dan prestasi yang dimaksudkan dalam penilaian portofolio adalah bukti-bukti fisik dan/atau pengesahannya oleh lembaga atau pejabat yang berwenang. Dalam mendukung keberhasilan peningkatan guru dalam jabatan, sangat besar.
Hal ini ditunjukkan peran TVE dalam memfasilitasi keberhasilan peningkatan kompetensi guru (kepribadian, pedagogi, profesional dan sosial) dengan adanya kesiapan penyelenggaraan TVE, baik dari sisi hardware dan software yang telah direncanakan secara mantap dan memadai. Hardware, seperti TV penerima, parabola dan stasiun relay TV lokal sudah tersedia di banyak kota/ kabupaten. Sedangkan software yang berupa berbagai program siaran pembelajaran, telah tersedia di Pustekkom. Dalam pelaksanaan program ini PUSTEKKOM bekerja sama dengan LPTK, P4TK dan LPMP merencanakan, memproduksi, menayangkan dan mengevaluasi program siaran 
pembelajaran dalam rangka meningkatkan kemampuan guru agar mampu menyusun persyaratan yang dibutuhkan dalam sertifikasi guru. Keseluruhan model penyelenggaraan ini disajikan dalam Gambar 11.

\section{PENUTUP}

\section{Kesimpulan}

Kualitas pendidikan akan meningkat kalau kualitas guru juga ditingkatkan. Hal ini sebanding lurus sebagai hukum sebab akibat. Saat ini jumlah guru yang perlu mendapatkan sertifikat sebagai guru

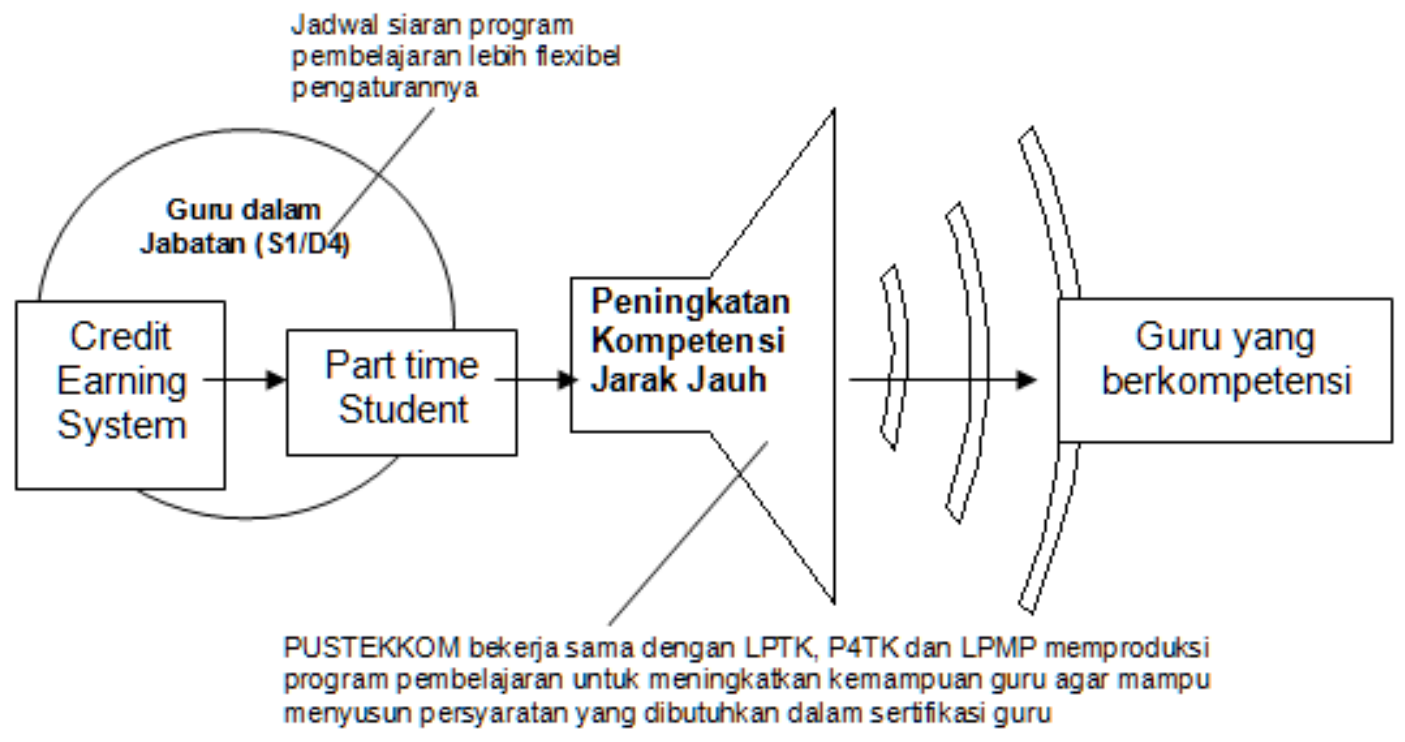

TVE dapat menayangkan materi-materi tentang penguatan kompetensi yang mendukung kesiapan guru untuk mengikuti uji sertifikasi. Paket materimateri tersebut antara lain: (1) Percepatan Implementasi Kurikulum 2006 (Kurikulum Tingkat Satuan Pendidikan - KTSP) Dalam Pembelajaran; (2) Penguatan Stategi Pembelajaran dalam KTSP; (3) Penguatan Bidang Studi; (4) Penguatan Penelitian Tindakan Kelas; (5) Penguatan Penulisan Karya IImiah; (6) Penguatan Penulisan Bahan Ajar; dan (7) Kiat Pengelolaan Jurnal Sekolah.

Untuk memproduksi ketujuh paket program tersebut, Pustekkom bekerjasama dengan LPTK, P4TK dan LPMP, serta lembaga-lembaga lain yang sangup dan layak memproduksi dan mengembangkan paket-paket pembelajaran yang dapat ditayangkan dalam program siaran TVE, untuk mendukung keberhasilan guru dalam menghadapi sertfikasi guru. profesional kurang lebih tiga juta. Jumlah yang begitu besar akan sulit dilakukan secara serentak apabila dalam rangka peningkatan kompetensi dan kualifikasinya hanya dilakukan secara konvensional. Untuk itu perlu dukungan berbagai sarana terutama yang berkitan dengan teknologi.

Siaran TVE yang saat ini dimiliki oleh Depdiknas, sudah selayaknya dimanfaatkan untuk mendukung dan mensosialisasikan berbagai kebijakan Dekdiknas, dan salah satunya program sertifikasi guru.

Dengan memanfaatkan TVE, informasi dan berbagai hal yang berkaitan dengan sertifikasi guru dengan mudah dan efisien sampai kepada guru di seluruh Indonesia. Di samping itu TVE juga dapat dimanfaatkan untuk terus meningkatkan kualitas guru baik yang sudah profesional agar terus terjaga profesionalitasnya, termasuk yang belum sehingga akhirnya dengan mudah mereka mendapatkan sertifikat guru profesional. 


\section{Saran-saran}

a. Saat ini siaran TVE Saluran 2 yang dikhususkan untuk guru masih belum banyak diketahui oleh guru, maka pihak Depdiknas (Pustekkom) perlu melakukan sosialisasi kepada guru secara optimal.

b. Agar sosialisasi Siaran TVE Saluran 2 dapat sampai kepada sasaran dengan cepat dan tepat, Pustekkom sebaiknya bekerjasama dengan pihak-pihak yang berhubungan langsung dengan guru, misalnya Dirjen PMPTK, LPMP, MGMP, dll.

c. Rumusan rancangan pemanfaatan siaran TVE untuk mendukung keberhasilan sertifikasi guru ini masih perlu dikaji oleh pihak-pihak terkait maupun oleh perguruan tinggi secara terus menerus. Selain itu hasil yang diperoleh dari diskusi ini perlu untuk dilakukan ujicoba.

\section{DAFTAR PUSTAKA}

Chaudhary, S.S. 1992. Television in Distance Education: The Indian Scene. In Indian
Journal of Open Learning, 1(1):23-31.

Chunjie, X. \& Yuxia,Z. 1994. Satellite Television Education in China: A Project of Teacher Training through Distance Education. Media and Technology for Human Resource Development, 6(2): 113-117.

Kuncoro, M. 2004. Otonomi dan Pembangunan Daerah: Reformas, Perencanaan, Strategi dan Peluang. Jakarta: Erlangga

Muchlas, S dan Mukhadis, A. 2006. Mengenal Sertifikasi Guru di Indonesia. Surabaya: Pernerbit SIC

Mukhadis, A. 2004. Standar dan Sertifikasi Kompetensi Refresentasi Penjamin Mutu Profesional Guru di Indonesia Pada Abad Pengetahuan. Surabaya: Seminar Nasional Pendidikan.

Mungin, E. W. 2004. Standar, Sertifikasi dan Lesensi Profesi Pendidik dan Tenaga Kependidikan. Surabaya: Seminar Nasional Pendidikan.

Mulyasa, E. 2004. Menjadi Guru Profesional. Bandung: Remaja Rosdakarya

Syaad, P. Djoko, S. dan Waras, K. 2006. Naskah Akademik Televisi Edukasi (TVE). Jakarta: Pustekkom

Undang--Undang Nomor 14 Tahun 2005 tentang Guru dan Dosen (UUGD). Bandung: Remaja Rosdakarya

Undang Undang Replublik Indonesia No 20 Tahun 2003 Tentang Sistem Pendidikan Nasional (Sisdiknas). Jakarta: Sinar Grafika 